Volume 3 Part 1 March 1983

AGEING

AND

SOCIETY 


\title{
AGEING AND SOCIETY
}

The Journal of

The Centre for Policy on Ageing and The British Society of Gerontology

Editor: MALCOLM L. JOHNSON

Policy Studies Institute, $I-2$ Castle Lane, London $S W_{I} E 6 D R$

Review Editor: REX TAYLOR

M.R.C. Medical Sociology Unit, Westburn Road, Aberdeen ABg $2 Z E$

\author{
Editorial Board \\ Mildred Blaxter (MRC Medical Sociology Unit, Aberdeen) \\ Dennis Bromley (University of Liverpool) \\ J. Grimley Evans (University of Newcastle upon Tyne) \\ Eileen Fairhurst (Sheffield Polytechnic) \\ Anne J. J. Gilmore (University of Glasgow) \\ Margot Jefferys (Bedford College, University of London) \\ Peter Laslett (Trinity College, Cambridge) \\ Alan Lipman (University of Wales) \\ Alison J. Norman (Centre for Policy on Ageing, London) \\ Robert Pinker (London School of Economics) \\ Hedley Taylor (Centre for Policy on Ageing, London) \\ Hilary Todd (Centre for Policy on Ageing, London) \\ Kenneth Wright (University of York) \\ Overseas Editorial Advisers \\ Eva Beverfelt (Institute of Gerontology, Oslo) \\ Françoise Cribier (Université de Paris I) \\ Neal Cutler (University of Southern California) \\ Michael Davies (Brookdale Institute of Gerontology, Jerusalem) \\ Anna Howe (University of Melbourne) \\ Daisaku Maeda (Tokyo Metropolitan Institute of Gerontology) \\ Victor Marshall (University of Toronto) \\ J. M. A. Munnichs (Katholieke Universiteit, Nijmegen) \\ Leopold Rosenmayr (University of Vienna) \\ Sheldon Tobin (The University of Chicago)
}

Ageing and Society is an international journal devoted to publishing contributions to the understanding of human ageing, particularly from the social and behavioural sciences and humanities. Its interpretation of ageing is wide and includes all aspects of the human condition whether they relate to individuals, groups, institutions or societies.

In addition to original articles the journal also carries a review section comprising book reviews and shorter notes, review articles and symposia, and an abstracts service intended to draw readers' attention to relevant articles in other journals.

Copying: This journal is registered with the Copyright Clearance Center, 2 I Congress St., Salem, Mass. org7o. Organizations in the USA who are also registered with C.C.C. may therefore copy material (beyond the limits permitted by sections 107 and 108 of U.S. copyright law) subject to payment to C.C.C. of the per-copy fee of \$05.00. This consent does not extend to multiple copying for promotional or commercial purposes. Code or $44-686 \mathrm{X} / 8_{3} /$ 0000-0001 \$05.00.

For all other use, permission should be sought from the Cambridge or New York offices of the Cambridge University Press.

Subscriptions: Ageing and Society (ISSN or 44-686X) is published in volumes of three parts in March, July and November. The subscription price (which includes postage) of volume 3, 1983 is $£ 17.00$ (US $\$ 25.00$ in USA and Canada) for institutions, $£ 24.00$ (US $\$ 49.50$ in USA and Canada) for individuals ordering direct from the Press and certifying that the journal is for their personal use. Single parts cost $£ 9.00$ net (US \$19.50 in USA and Canada) plus postage. Orders, which must be accompanied by payment, may be sent to a bookseller, subscription agent or direct to the publishers: Cambridge University Press, The Edinburgh Building, Shaftesbury Road, Cambridge $\mathrm{CB}_{2} 2 \mathrm{RU}$. Orders from the USA or Canada should be sent to Cambridge University Press, 32 East 57 th Street, New York, NY 10022, USA. Copies of the journal for subscribers in the USA and Canada are sent by air to New York to arrive with minimum delay. 